\title{
Islet cell antibodies and the development of diabetes mellitus in relation to mumps infection and mumps vaccination
}

\author{
K. Helmke ${ }^{1}$, A. Otten ${ }^{2}$, W. R. Willems ${ }^{3}$, R. Brockhaus ${ }^{1}$, G. Mueller-Eckhardt ${ }^{4}$, T. Stief ${ }^{4}$, J. Bertrams ${ }^{5}$, H. Wolf ${ }^{2}$ \\ and K. Federlin ${ }^{1}$ \\ Departments of ${ }^{1}$ Internal Medicine, ${ }^{2}$ Paediatrics, ${ }^{3}$ Medical Virology and ${ }^{4}$ Clinical Immunology and Blood Transfusion, University of Giessen; \\ ${ }^{5}$ Elisabeth Hospital, Essen, FRG
}

\begin{abstract}
Summary. Islet cell antibodies were investigated in 127 nondiabetic children after mumps infection and in four out of seven children who developed diabetes mellitus shortly after active mumps vaccination. Twenty-one of the children who had mumps and all four vaccinated children who were tested had islet cell cytoplasmic antibodies. In contrast, islet cell surface antibodies were detected in 43 out of 68 patients with mumps infection and in 32 out of 44 patients with other viral diseases.
\end{abstract}

All but one mumps-infected child and all the other viral infected patients investigated did not develop diabetes mellitus. The mumps-infected ICA positive children did not show those HLA-frequencies associated with Type 1 diabetes.

Key words: Islet cell antibodies, Type 1 diabetes mellitus, mumps infection, virus infections, autoimmunity.
Mumps and other viral infections have repeatedly been linked with the development of diabetes mellitus. Observations of diabetes occurring shortly after mumps infection date back to the last century and continue to recent years [1-4].

In 1979, we found islet cell cytoplasmic antibodies (ICA) in the serum of a girl who developed Type 1 diabetes three weeks after mumps infection [5]. This observation prompted us to search further for islet cell antibodies in serum samples of mumps-infected children and to study prospectively their islet cell antibody titre and glucose metabolism. Besides cytoplasmic ICA, islet cell surface antibodies (ICSA) and the HLA-type were determined. In addition, data were collected from 7 children who developed diabetes mellitus after active mumps immunization.

\section{Subjects and methods}

\section{Patients}

Serum samples from 127 children seen at the children's hospital of the University of Giessen because of mumps complications such as meningoencephalitis and pancreatitis were investigated over the last 5 years. As children with mumps without complications do not usually attend hospital, our patients constitute a selected population. Three children developed diabetes mellitus after mumps vaccination. Data from a further three vaccinated children were kindly provided by Prof. Ehrengut (Medical Director of the Public Health Department, Hamburg, FRG) and of one additional child by Prof. Zuppinger (Children's Hospital, Berne, Switzerland). Sera from these children were analysed for ICA by the indirect immunofluorescence technique. Forty-four serum specimens of patients with viral infections other than mumps and 40 sera from control subjects without known viral infections or disturbed glucose tolerance were investigated in the same way.

\begin{abstract}
Methods
Complement-fixing islet cell antibodies (CF-ICA) and non-complement-fixing cytoplasmic islet cell antibodies (ICA) were detected by the indirect immunofluorescence technique on fresh frozen blood group 0 human pancreas as described by Bottazzo and coworkers [6]. ICSA were investigated by the use of suspensions of isolated rat islet cells after collagenase and trypsin digestion according to Lernmark et al. [7] with slight modifications. As a first step, the sera to be tested were absorbed with rat liver cells as well as spleen cells. Mumps antibodies were determined by the complement fixation test [8]. A significant rise in antibody titre was not obtained in all cases, since the serum samples could not always be drawn at the appropriate time in the course of the disease. HLA-typing was carried out in 45 mumps-infected children from heparinized blood by the lymphocytotoxicity test. For DR-typing, B lymphocytes were prepared using a nylon wool column as described recently [9].
\end{abstract}

\section{Results}

Out of 127 sera from children with severe mumps infections, 21 were ICA-positive (Fig.1). There was a very high prevalence of ICA in serum samples investigated in 1979 to 1981 and a decrease of the ICA-incidence in subsequent years. In 1979 to 80,13 out of 26 mumps-infected patients showed ICA. During the following seasons, 7 out of 25 (1980-81), 1 out of $27(1981-82)$ and none out of 49 (1982-83 and 1983-84) were positive (Fig. 1).

These discrepancies were confirmed by retesting sera obtained at different times together on the same source of human pancreas after 2-4 years storage at $-70^{\circ} \mathrm{C}$ with comparable results (Fig. 2). Thus technical reasons for these differences could be largely ruled out $(r=0.961$, Spearman rank test). About $50 \%$ (11 out of 21 ) of the ICA detected in these patients fixed complement. The CF-ICA were almost exclusively of medium 
or high titre, ranging from $1: 8$ to $1: 128$ (Fig. 1). In 44 serum samples of patients suffering from other viral infections such as coxsackie, measles, rubella and adenoviruses, ICA were undetectable. On the other hand, ICSA were found in 42 out of 68 sera from children (62\%) with mumps infection and in 32 sera from 44 patients $(73 \%)$ with other viral diseases. In the control group $(n=40)$, there was one positive ICA test at $1: 4(2.5 \%)$ and six positive ICSA tests at $1: 2$ and $1: 4$ (14\%) (Fig. 3). During the observation period (1979-1983), there was no significant yearly variation in the incidence and titre of ICSA in sera from patients studied suffering from viral infections (Fig. 4). All but one of these patients

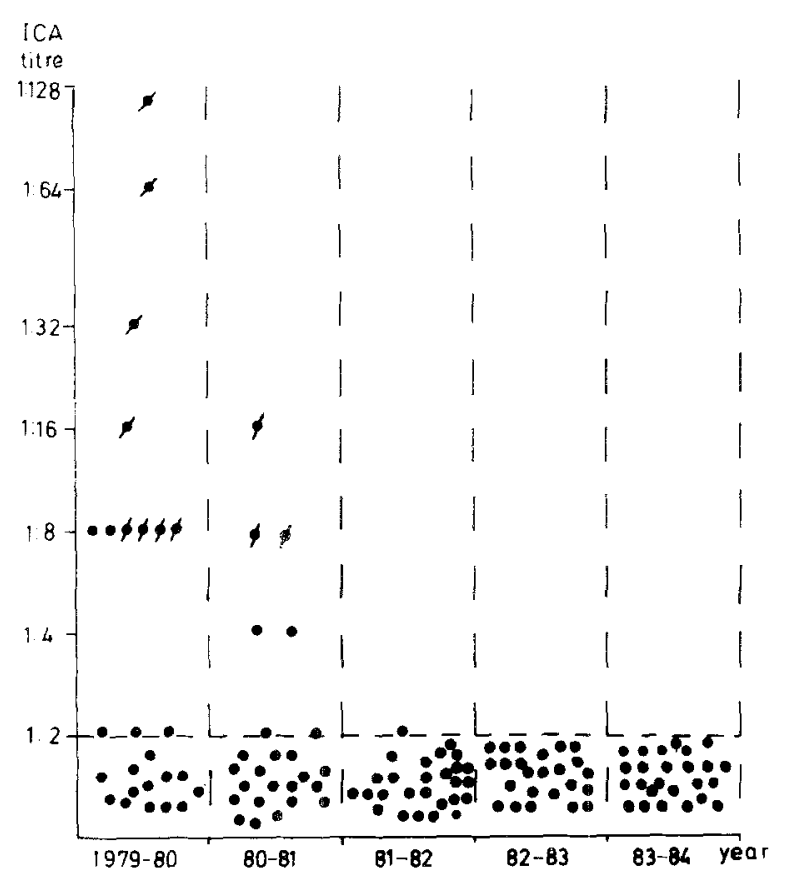

Fig. 1. Islet cell cytoplasmic antibodies (ICA - ) and complementfixing islet cell antibodies (CF-ICA, $\boldsymbol{\sigma}$ ) in mumps-infected children between 1979 and June 1984 had normal glucose tolerance over the subsequent 3 to 5 years. However, the one child who developed diabetes mellitus 3 weeks after mumps infection was the only one who showed persistence of ICA for 9 months (Fig. 5). Newly diagnosed Type 1 diabetic patients at our centre did not show significant variations in incidence of the disease or ICA titre over that period of time. In 45 (1979-81) and 64 (1981-84) patients, ICA were detectable in $88 \%$ and $91 \%$ respectively. HLA-typing of 14 ICA-positive non-diabetic children did not show significantly increased frequencies of DR3 and/or DR 4 compared with normal subjects as seen in Type 1 diabetic subjects (Table 1). In contrast with this group of

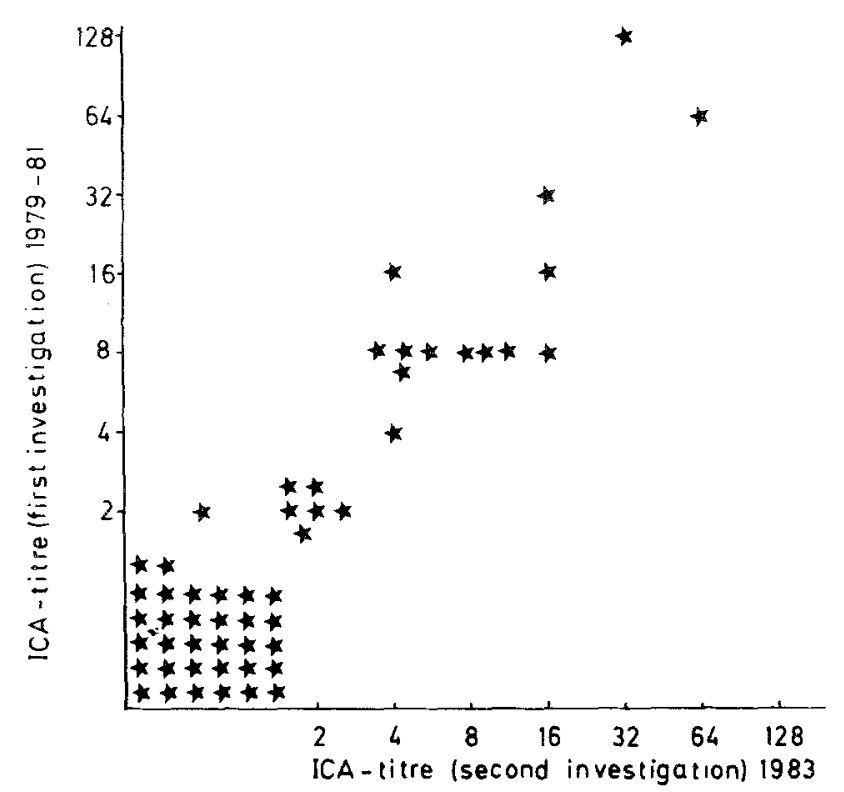

Fig. 2. Results of ICA detection in 51 mumps-infected children at the time of first investigation and after 2-4 years storage retested on another piece of human pancreas

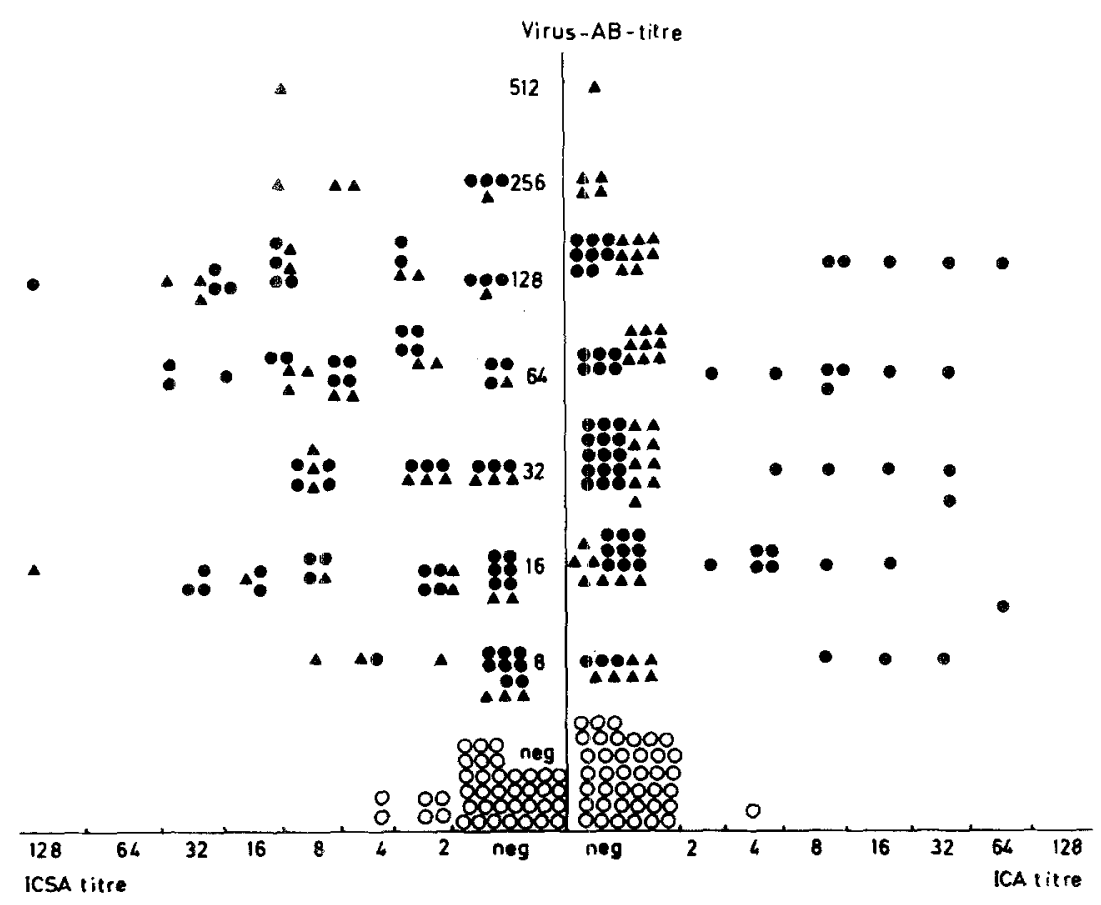

Fig.3. ICA and ICSA in patients with mumps $(-n=68)$ and other virus infections $(\Delta n=44)$ in relation to the virus antibody titres compared with control subjects ( $\mathrm{O} n=40$ ) without viral infections 
patients, DR3 and/or DR 4 were found in all children who developed diabetes mellitus two to four weeks after mumps vaccination (Table 2). All children of that group were positive for DR4 and, in addition, three for DR3. All of those patients tested were also ICA-positive.

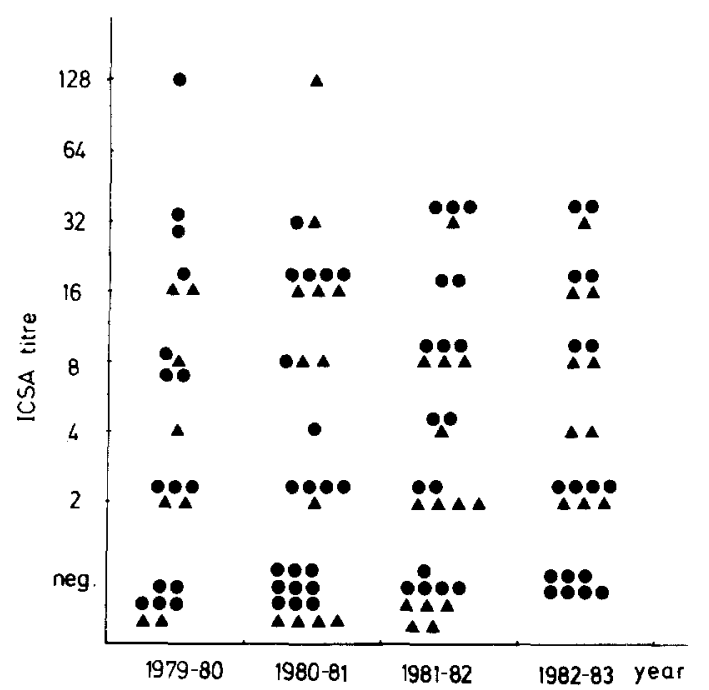

Fig.4. ICSA: incidence and titre in 68 patients with mumps $(\boldsymbol{O})$ and 44 patients with other viral $(\boldsymbol{\Delta})$ infections during 1979 to 1983

\section{Discussion}

In view of the numerous case reports of diabetes occuring after mumps [10-14], it is tempting to speculate about a causal relationship. As there is a high incidence of such virus infections, however, one should consider

Table 1. HLA-type of 17 mumps-infected children

\begin{tabular}{|c|c|c|c|c|c|c|c|}
\hline \multirow[t]{2}{*}{ Patient } & \multirow{2}{*}{$\begin{array}{l}\text { Age } \\
\text { (years) }\end{array}$} & \multirow[t]{2}{*}{ Sex } & \multirow{2}{*}{$\begin{array}{l}\text { ICA } \\
\text { Titer }\end{array}$} & \multicolumn{4}{|c|}{ HLA phenotype } \\
\hline & & & & A & $\mathrm{B}$ & $\mathrm{C}$ & DR \\
\hline 1 & 4 & M & $1: 2$ & 1.29 & 14.38 & w8.- & 1.5 \\
\hline 2 & 5 & $F$ & $1: 8$ & 2.24 & 7.62 & w3.- & 2.4 \\
\hline 3 & 5 & M & $1: 8$ & 24.w33 & 44.35 & W4.- & 5.- \\
\hline 4 & 5 & $\mathrm{~F}$ & $1: 16$ & 26.28 & 38.w57 &,-- & 1.w6 \\
\hline 5 & 7 & $\mathrm{~F}$ & $1: 1$ & 3.24 & 18.27 & w2.- & 4.5 \\
\hline 6 & 8 & M & $1: 2$ & 24.29 & 44.w62 & w3.- & 7.- \\
\hline 7 & 8 & M & $1: 8$ & 3.24 & 13.w60 & w3.w6 & 3.w6 \\
\hline 8 & 9 & M & $1: 16$ & 23.28 & 44.51 & w4.-- & w6.- \\
\hline 9 & 10 & M & $1: 2$ & 2.24 & 39.44 & w5.- & 4.w8 \\
\hline 10 & 10 & $\mathrm{~F}$ & $1: 1$ & 23.24 & 44.w53 & w4.- & 2.7 \\
\hline 11 & 11 & $\mathrm{~F}$ & $1: 2$ & 2.3 & 7.w62 & w3.- & 5.7 \\
\hline 12 & 12 & M & $1: 16$ & 2.11 & 18.44 &.-- & 4.5 \\
\hline 13 & 13 & $\mathrm{~F}$ & $1: 1$ & 24.30 & 35.45 & w4.- & 5.- \\
\hline 14 & 19 & M & $1: 32$ & 2.3 & 44.w60 & w3.w5 & 4.w6 \\
\hline 15 & 8 & M & $\emptyset$ & 1.2 & 8.44 &.-- & 3.4 \\
\hline 16 & 10 & M & $\emptyset$ & 1.32 & 8.44 & w5.- & 3.4 \\
\hline 17 & 12 & $\mathrm{~F}$ & $\emptyset$ & 1.w23 & 8.w49 & w3.- & 3.4 \\
\hline
\end{tabular}

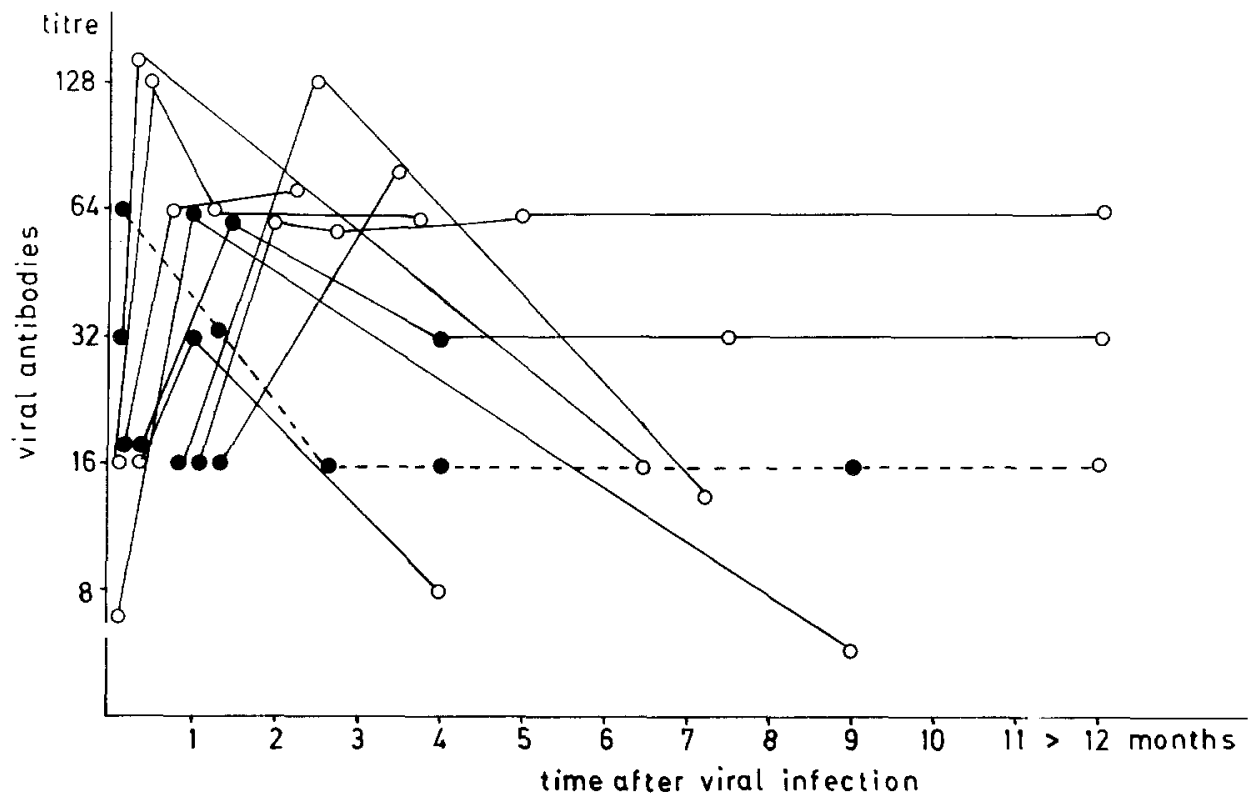

Fig.5. Virus antibody titre and ICA in 10 mumps-infected children followed over a period of 12 months. The broken line represents the ICA in the child who developed diabetes mellitus. $=$ ICA-positive, $O=I C A-n e g-$ ative

Table 2. HLA, ICA and age at onset of diabetes in seven patients after mumps (m) or combined mumps-measles (mm) vaccination

\begin{tabular}{|c|c|c|c|c|c|c|c|c|c|}
\hline \multirow[t]{2}{*}{ Patients } & \multirow{2}{*}{$\begin{array}{l}\text { Age at onset of } \\
\text { diabetes mellitus }\end{array}$} & \multirow{2}{*}{$\begin{array}{l}\text { ICA } \\
\text { Titer }\end{array}$} & \multirow[t]{2}{*}{ Sex } & \multirow[t]{2}{*}{ Vaccination } & \multirow{2}{*}{$\begin{array}{l}\text { Interval between vaccination } \\
\text { and onset of diabetes }\end{array}$} & \multicolumn{4}{|c|}{ HLA phenotype } \\
\hline & & & & & & A & B & $\mathrm{C}$ & DR \\
\hline 1 & 2 & N.D. & $\mathrm{F}$ & $\mathrm{mm}$ & $3^{\text {rd }}$ week & 1.2 & 8.w60 & w3.- & 3.4 \\
\hline 2 & 16 & $1: 32$ & M & $\mathrm{m}$ & $4^{\text {th }}$ week & 2.3 & 44.w60 & w3.w5 & 4.w6 \\
\hline 3 & 3 & $1: 2$ & $\mathbf{M}$ & $\mathrm{mm}$ & $2^{\text {nd }}$ week & 2.32 & 8.w62 & w3.- & 3.4 \\
\hline 4 & 2 & $1: 8$ & M & $\mathrm{mm}$ & $4^{\text {th }}$ week & 2.24 & 44.51 &.-- & 4.w6 \\
\hline 5 & 16 & N.D. & M & $\mathrm{mm}$ & $2^{\text {nd }}$ week & 2.3 & 44.w60 & w3.w7 & 4.w6 \\
\hline 6 & 2 & N.D. & $\mathrm{F}$ & $\mathrm{m}$ & $2^{\text {nd }}$ week & 1.30 & 8.13 & w4.w6 & 3.4 \\
\hline 7 & 2 & $1: 16$ & $\mathrm{~F}$ & $\mathrm{~m}$ & $3^{\text {rd }}$ week & 2.3 & w35.40 & w3.w4 & 1.4 \\
\hline
\end{tabular}


that the occurence of diabetes after mumps could be fortuitous. It would be desirable that such considerations either are substantiated or disproven by a comparison of the real frequency of such events with a statistical probability of the occurence by chance. To our knowledge, this approach has not been taken. It would involve a prospective study of considerable dimensions.

Therefore we found it worthwhile to try what might be called a second-best approach. We tested such patients for ICA, ICSA and determined their HLA-type; we did not specifically look for other antibodies such as rheumatoid factor. Compared with normal subjects, there was no significant difference of HLA-frequencies in the ICA-positive group of mumps-infected patients nor any difference from the ICA-negative group of patients, as suggested previously [9]. The typical HLA-associations as established for Type 1 diabetes [15] were not seen in ICA-positive mumps patients (Table 1). Even in patients with both DR3 and DR4, exposure to the mumps virus did not lead to production of ICA in all cases or onset of diabetes mellitus as could be seen in three ICA negative children (Table 1, cases 15-17).

This, together with the negative results reported by other investigators [16], indicates that some additional predisposing factors are needed for the development of Type 1 diabetes. Our initial finding of a frequency of greater than $50 \%$ of ICA in mumps patients [5] has decreased to zero during recent years. There was a high correlation between the concentration of ICA detected and its complement fixation (Fig.1). Similar observations were reported recently for Type 1 diabetic patients $[17,18]$.

At present, we cannot explain this, although it may be due to differences between the mumps virus strains circulating in the population at different times, as shown by the use of monoclonal antibodies [19].

Few children developed diabetes after mumps vaccination and only one child after mumps infection. Taking these single observations together with other anecdotal case reports, it is remarkable that it is usually coxsackie B or mumps infection which is reported in connection with the onset of Type 1 diabetes [1-3, 20, 21]. The virus infection was usually observed shortly, i.e. a few weeks, before diabetes appeared. Over the past few years, however, evidence has accumulated that a period of many years may be required for the disease to develop [22]. Thus it seems highly unlikely to us that, in the cases reported, the onset of diabetes is primarily due to the recent virus infection or active vaccination. A virus infection, however, could be the final insult to the immune system or islets which are undergoing destructive autoimmune processes leading to the onset of clinical diabetes.

Acknowledgement. We are grateful to Ms. S. Kienappel for preparing the manuscript and to Ms. M. Brückel and Ms. S. Kienappel for skillful technical assistance.

\section{References}

1. Harris HF (1899) A case of diabetes mellitus quickly following mumps. Boston Med Surg J 140: 465-469

2. McCrae WM (1963) Diabetes mellitus following mumps. Lancet 1: $1300-1301$

3. Peig M, Ercilla G, Milian M, Gomis R (1981) Post-mumps diabetes mellitus. Lancet 1: 1007 (Letter)

4. Toniolo A, Onodera T (1979) Viruses and diabetes. In: Andreani D, Federlin K, DiMario O, Heding LG (eds) Immunology in diabetes. Kimpton Medical Publications, London, pp 71-93

5. Helmke K, Otten A, Willems W (1980) Islet cell antibodies in children with mumpsinfection. Lancet 2: 211-212 (Letter)

6. Bottazzo GF, Dean BM, Gorsuch AN, Cudworth AG, Doniach D (1980) Complement-fixing islet cell antibodies in Type I diabetes: Possible monitors of active beta-cell damage. Lancet 1:668-672

7. Lernmark A, Reedmann ZR, Hofmann C, Rubinstein AH, Steiner DF, Jackson RL, Winter RJ, Traisman HS (1978) Islet cell surface antibodies in juvenile diabetes mellitus. New Engl J Med 299: 375-380

8. Terasaki PI, McClelland JD (1964) Microdroplet assay human serum cytotoxins. Nature 204: $998-1000$

9. Mueller-Eckhardt G, Stief T, Otten A, Helmke K, Willems WR, Mueller-Eckhardt C (1984) Complications of mumps infection, islet cell antibodies and HLA. Immunobiol 167: 338-344

10. Sinaniotis CA, Daskalopoulon E, Lapatsanis P, Doxiadis S (1975) Diabetes mellitus after mumps vaccination. Arch Dis Childhood 50: 749-750 (Letter)

11. Menser MA, Forrest JM, Bransby RD (1978) Rubella infection and diabetes mellitus. Lancet 1: 57-60

12. Gamble DR (1980) Relation of antecedent illness to development of diabetes in children. $\mathrm{Br}$ Med J 281:99-101

13. Ratzmann KP, Streu J, Witt S, Berling H, Keilacker H, Michaelis D (1984) Mumps infection and insulin-dependent diabetes mellitus (IDDM). Diabetes Care 7: 170-173

14. Rayfield EJ, Seto Y (1978) Viruses and the pathogenesis of diabetes mellitus. Diabetes 27: 1126-1139

15. Pyke DA (1979) The genetic connections. Diabetologia 17: 333-343

16. Richens ER, Jones WG (1981) Islet cell antibodies and mumps. Lancet 1: 507-508 (Letter)

17. Bruining $\mathrm{G}$, Molenaar JJ, Tuk CW, Lindemann J, Bruining HA, Maerner B (1984) Clinical time-course and characteristics of islet cell cytoplasmatic antibodies in childhood diabetes. Diabetologia 26: $24-29$

18. Gleichmann H, Zörcher B, Greulich B, Gries FA, Henrichs HR, Bertrams J, Kolb H (1984) Correlation of islet cell antibodies and HLA-DR phenotypes with diabetes mellitus in adult. Diabetologia $27: 90-92$

19. Örvell C (1984) The reactions of monoclonal antibodies with structural proteins of mumps virus. J Immunol 132: 2622-2629

20. Yoon JW, Austin M, Onodera T, Notkins AL (1979) Virus-induced diabetes mellitus: isolation of a virus from the pancreas of a child with diabetic ketoacidosis. New Engl J Med 300: 1173-1179

21. Champasur HF, Bottazzo GF (1982) Virologic immunologic and genetic factors in insulin-dependent diabetes mellitus. J Pediatrics 100: $15-20$

22. Gorsuch AN, Spencer KM, Lister J, McNally JM, Dean BM, Bottazzo GF, Cudworth AG (1981) Evidence for a long pre-diabetic period in Type 1 (insulin-dependent) diabetes mellitus. Lancet 2: 1363-1365

Received: 7 February 1985

and in revised form: 11 November 1985

Dr. Klaus Helmke

Med. Klinik III und Poliklinik

der Justus Liebig-Universität Giessen

Rodthohl 6

D-6300 Giessen

FRG 